\title{
MULTIPLE NITROGEN AND PHOSPHORUS DEFICIENCY IN Zantedeschia
}

\author{
Deficiência múltipla de nitrogênio e fósforo em copo-de-leite
}

\author{
Katiúcia Dias Fernandes ${ }^{1}$, Patrícia Duarte de Oliveira Paiva², Janice Guedes de Carvalho ${ }^{3}$, \\ Aiesca Cecília Resende ${ }^{4}$, Madeleine Alves de Figueiredo ${ }^{4}$
}

\begin{abstract}
Multiple nutritional deficiencies are considered one of several factors that can induce doubt in the diagnosis based only in visual symptoms, because it makes identification more difficult. The aim of this work was to evaluate the development of Zantedeschia and the morphological changes resulting from nutritional disorders caused by multiple and simple nitrogen and phosphorus deficiency in plants grown in nutrient solution. Zantedeschia plants were grown for a period of eight months in a complete Hoagland and Arnon (1950) solution, with nitrogen (-N) omission, with phosphorus (-P) omission, with nitrogen and phosphorus (-NP) omission, and also nutrient solution with $\mathrm{N}$ and $\mathrm{P}$ at concentrations of 25,50 and $75 \%$, totalizing 7 treatments, with 4 replicates in a completely randomized experimental design. At the end of the experimental period, plant height, number of emitted leaves, leaf size, number and mineral composition of shoots were assessed. The omission of nutrients both in simple and multiple forms affected plant development. The highest shoot formation occurred in plants grown in solution and with 50\% of the concentration of NP. The mineral composition of macronutrients present in leaves and shoots of plants was influenced by multiple deficiencies of $\mathrm{N}$ and $\mathrm{P}$.
\end{abstract}

Index terms: Zantedeschia aethiopica, multiple omission, macronutrient, cut flower, calla lily.

\section{RESUMO}

A deficiência múltipla é considerada um dos vários fatores que pode induzir dúvidas na diagnose baseada apenas na sintomatologia, pois torna a identificação mais difícil. Assim, objetivou-se avaliar o desenvolvimento de copo-de-leite (Zantedeschia aethiopica) e as alterações morfológicas decorrentes da desordem nutricional provocada pela omissão múltipla e isolada de nitrogênio e fósforo em plantas cultivadas em solução nutritiva. O copo-de-leite foi cultivado por um período de 8 meses em solução de Hoagland e Arnon (1950) completa e com omissão simples de nitrogênio (N), de fósforo (P) e múltipla de NP e, ainda, solução nutritiva com NP nas concentrações, na proporção de 25,50 e $75 \%$, totalizando 7 tratamentos, com 4 repetições e delineamento experimental inteiramente casualizado. Ao final do período experimental foi avaliada a altura das plantas, o número de folhas emitidas, número de brotos e a composição mineral da parte aérea. A omissão de nutrientes tanto na forma simples quanto múltipla afetou o desenvolvimento das plantas. A maior formação de brotos ocorreu em plantas cultivadas em solução completa e com $50 \%$ da concentração de NP. A composição mineral dos macronutrientes presentes em folhas e brotos das plantas foi influenciada pela deficiência múltipla de $\mathrm{N}$ e $\mathrm{P}$.

Termos para indexação: Zantedeschia aethiopica, omissão múltipla, macronutriente, flor de corte, calla lily.

\section{(Received in july 25, 2012 and approved in october 31, 2012)}

\section{INTRODUCTION}

Zantedeschia or calla lily [Zantedeschia aethiopica (L.) Spreng.] is a perennial, rhizomatous plant, grown as cut flower and garden plant, which is grown mainly in the Southeast region of Brazil (ALMEIDA et al., 2009; LANDGRAF; PAIVA, 2009).

Plants that reach about $90 \mathrm{~cm}$ in height (CARNEIRO et al., 2011), present green leaves, forming clumps due to the rhizome, which has many growth points and whose leaf buds can be divided to produce seedlings. Both the number and height of leaf buds produced are important variables, since the division of leaf buds and rhizomes is the primary method of propagation of the species (CARNEIRO et al., 2011). To achieve better quality, a proper balance of nutrients is required, since they are directly related to the formation of vegetative and flowering stems (MALAVOLTA, 2006). Nitrogen (N) is one of the most abundant elements in plants and plants with $\mathrm{N}$ deficiency have general chlorosis, slow and delayed growth and plants show a stunted appearance (EPSTEIN; BLOOM, 2006). The dark-green color of leaves is one of the first symptoms of $\mathrm{P}$ deficiency in many species, growth is reduced and, in conditions of severe deficiency, plants become dwarf (EPSTEIN; BLOOM, 2006).

Nutrient deficiency causes metabolic disturbances that manifest in visible symptoms such as reduced growth and yellowing. Among the factors that may induce doubt in the identification of nutritional deficiencies, multiple

\footnotetext{
1Universidade Federal de Lavras/UFLA - Departmento de Agricultura/DAG - 37200-000 - Lavras - MG - Brasil - katiuciadf@gmail.com.br

2Universidade Federal de Lavras/UFLA - Departmento de Agricultura/DAG - 37200-000 - Lavras - MG - Brasil

3Universidade Federal de Lavras/UFLA - Departmento de Ciência do Solo/DCS - Lavras - MG - Brasil

${ }^{4}$ Universidade Federal de Lavras/UFLA - Lavras - MG - Brasil
} 
deficiencies stand out. Plants may have nutritional deficiency of two or more elements, which makes identification more difficult than when they occur alone (EPSTEIN; BLOOM, 2006).

Salvador et al. (1999) assessed the effects of single and multiple omissions of two nutrients in guava plants and observed that the visual symptoms in plants with multiple deficiencies are similar and intensified when compared with symptoms of simple deficiency.

Thus, the aim of this work was to evaluate changes in the development and nutritional status of calla lily plants caused by multiple omissions of nitrogen and phosphorus.

\section{MATERIAL AND METHODS}

Seedlings were micropropagated and acclimatized in a greenhouse with an intermittent mist for a period of 60 days in 24-cell plastic trays containing Plantmax ${ }^{\circledR}$, a commercial substrate. The seedlings were transferred to 36 L plastic trays of complete Hoagland and Arnon (1950) solution no. 2, with constant aeration, diluted to $20 \%$ and $30 \%$ of its ionic strength over a period of 20 days at each concentration for adaptation. After this period, plants were placed in separate vessels of $3 \mathrm{~L}$, fixed by means of a polystyrene plate of $30 \mathrm{~cm}$ in diameter and $4 \mathrm{~cm}$ thick. The nutrient solution was maintained under constant aeration for the entire experimental period, with replacements every two weeks. In the interval for the renewal of solutions, the volume of vessels was filled with deionized water whenever necessary. The experiment was kept under 50\% shading cloth arranged within the greenhouse.

The experimental design was completely randomized with seven treatments and four replications, two plants per plot and one plant per pot. The experiments used complete Hoagland and Arnon solution (1950), with $\mathrm{N}(-\mathrm{N})$ omission, with $\mathrm{P}(-\mathrm{P})$ omission, with $\mathrm{N}$ and $\mathrm{P}$ (-NP) omission and $\mathrm{N}$ and $\mathrm{P}$ at concentrations of $25 \%, 50 \%$ and $75 \%$ totalizing 7 treatments, with 4 replicates in a completely randomized experimental design.

At the end of the experimental period, plant height, leaf number, and number of leaf buds were measured. Leaves and leaf buds were identified and dried in a convection oven at $65^{\circ} \mathrm{C}-70^{\circ} \mathrm{C}$ until constant weight. The dry mass of leaves and leaf buds were determined and grinding in Willey-type mill was performed for subsequent chemical analysis to determine the $\mathrm{N}, \mathrm{P}, \mathrm{K}, \mathrm{Ca}, \mathrm{Mg}, \mathrm{S}, \mathrm{B}$, $\mathrm{Cu}, \mathrm{Fe}, \mathrm{Zn}$ and $\mathrm{Mn}$ levels, according to methods described by Malavolta et al. (1997). The nutrient accumulation was determined by multiplying the nutrient content by the corresponding dry mass. Data obtained were submitted to analysis of variance and means were compared by the ScottKnott test ( $p \leq 0.05)$, with the aid of SISVAR statistical software (FERREIRA, 2011).

\section{RESULTS AND DISCUSSION}

\section{Deficiency symptoms and biometric indexes}

After 120 days, plants grown in solution with multiple $\mathrm{N}$ and $\mathrm{P}$ deficiency showed leaf blade and petiole chlorosis in older leaves. Over time, the symptoms developed to a yellowish color around the leaf blade of older leaves followed by drying. Salvador et al. (1998) described the visual symptoms of multiple $\mathrm{N}$ and $\mathrm{P}$ deficiency in guava seedlings as an initial general chlorosis, followed by internerval dark-red spots in older leaves and of lower intensity in middle ones, with the occurrence of reddish necrotic points at the apex of older leaves. In zantedeschia, yellowing of the leaf blade of older leaves followed by drying was also observed, as well as a lower number of leaves compared to plants grown in the complete solution.

At 150 days of the experimental period, plants showed reduced development, with a lower number of leaves compared to plants grown in the complete solution (Table 1). Carneiro et al. (2011) observed that the average production of zantedeschia leaves was 6.78 leaves per plant in an experiment of nutrient accumulation. Differences in plant heights were observed: plants grown in solution with -N, -NP and 50 NP exhibited lower heights.

After 180 days of treatment, there was no purple color in the edges toward the center of older leaves, which is a characteristic symptom of $\mathrm{P}$ deficiency as described by Epstein and Bloom (2006). Symptoms of N deficiency may have masked the symptoms of P deficiency, which is the greatest difficulty in visual diagnosis, once there is deficiency of both nutrients but only one expresses the characteristic symptom. Carneiro et al. (2011) observed that $\mathrm{P}$ was the third nutrient least required by calla lily plants in the early developmental stage. This demonstrates the lower requirement of this nutrient in calla lily plants in the early development stage: $\mathrm{P}$ present in rhizome and root, added to $\mathrm{P}$ adsorbed in the adaptation phase (complete solution) were sufficient to maintain the growth of plants in this period.

Plants showed characteristic deficiency symptoms in leaves when grown in solution with the simple omission of $\mathrm{N}$ and $\mathrm{P}$ and also multiple omissions of $\mathrm{N}$ and $\mathrm{P}$. Differences were not detected in symptoms of plants grown in solution with single and multiple omissions of $\mathrm{N}$ and $\mathrm{P}$. 
Table 1 - Leaf number, plant height (height), dry mass of leaves and leaf buds, number of leaf buds (Buds) in zantedeschia plants grown in complete Hoagland and Arnon (1950) solution and with N (-N) omission, with P (-P) omission, with N and $\mathrm{P}(-\mathrm{NP})$ omission and $\mathrm{N}$ and $\mathrm{P}$ at concentrations of $25 \%, 50 \%$ and $75 \%$.

\begin{tabular}{cccccc}
\hline Solutions & Leaf number & Height $(\mathrm{cm})$ & Dry mass of leaves $(\mathrm{g})$ & Buds & Dry mass of buds $(\mathrm{g})$ \\
\hline Complete & $5.00 \mathrm{a}$ & $73.00 \mathrm{a}$ & $11.02 \mathrm{a}$ & $28.25 \mathrm{a}$ & $11.33 \mathrm{a}$ \\
$75 \mathrm{NP}$ & $4.75 \mathrm{~b}$ & $67.25 \mathrm{a}$ & $7.87 \mathrm{~b}$ & $21.28 \mathrm{~b}$ & $6.14 \mathrm{~b}$ \\
$50 \mathrm{NP}$ & $4.50 \mathrm{~b}$ & $59.00 \mathrm{a}$ & $9.03 \mathrm{~b}$ & $30.37 \mathrm{a}$ & $10.47 \mathrm{a}$ \\
$25 \mathrm{NP}$ & $4.50 \mathrm{~b}$ & $64.75 \mathrm{a}$ & $8.77 \mathrm{~b}$ & $20.71 \mathrm{~b}$ & $4.79 \mathrm{~b}$ \\
-NP & $3.50 \mathrm{~b}$ & $65.50 \mathrm{a}$ & $5.92 \mathrm{c}$ & $16.37 \mathrm{~b}$ & $7.58 \mathrm{~b}$ \\
\hline -N & $4.00 \mathrm{~b}$ & $59.25 \mathrm{a}$ & $9.26 \mathrm{~b}$ & $21.62 \mathrm{~b}$ & $5.28 \mathrm{~b}$ \\
$-\mathrm{P}$ & $4.50 \mathrm{~b}$ & $70.00 \mathrm{a}$ & $6.17 \mathrm{c}$ & $12.00 \mathrm{~b}$ & $4.72 \mathrm{~b}$ \\
\hline
\end{tabular}

Averages followed by same letter in columns do not differ by the Scott-Knott test at $5 \%$.

Plants grown in complete solution showed an average height of $73.00 \mathrm{~cm}$ at 240 days of growth. No difference was observed in height of plants grown in solution with single and multiple omissions of $\mathrm{N}$ and $\mathrm{P}$. This could have occurred because the plants were still in early stages of development. At 210 days of growth, Carneiro et al. (2011) observed that zantedeschia plants showed $91.46 \mathrm{~cm}$ in height. This difference can be due to the different substrate used and size of the pot. Lobo et al. (2012) also observed no differences in height and leaf dry mass of peanut plants grown in solution with the omission of $\mathrm{N}$ and NP.

Plants grown in solution with the omission of macronutrients showed lower dry mass yield when compared to those grown in the complete solution, and the omission of NP and Pyielded lower values (Table 1). This result may have been influenced by the nutrient with the lowest content, in this case P. Frazão et al. (2010), also observed lower dry mass yield in torch ginger [Etlingera elatior (Jack) R.M. Sm.] grown in solution with simple omission of $\mathrm{N}$ and $\mathrm{P}$.

The number of leaf buds was higher in plants grown in either the complete solution and with $50 \mathrm{NP}$; even as the dry mass of leaf buds was similar to that of plants grown in the complete solution and with $50 \mathrm{NP}$ (Table 1). Carneiro et al. (2011) worked with zantedeschia plants and observed the formation of 29.30 leaf buds per plant, which was close to those observed in plants grown in complete solution, i.e., 28.25 leaf buds per plant.

\section{Content and accumulation of nutrients in zantedeschia leaves}

Table 2 shows that with a reduction of $\mathrm{N}$ in the solutions, there is a low content of $\mathrm{N}$ in zantedeschia leaves. The low $\mathrm{N}$ levels followed by low dry mass yield resulted in lower accumulation of this nutrient in plants grown in solution with NP deficiency. Both the $P$ content and accumulation in calla lily leaves were influenced by the multiple $\mathrm{N}$ and $\mathrm{P}$ deficiency in the solution.

Plants grown in solution with $25 \mathrm{NP}$ and omission of NP and P showed high S levels in leaves, followed by low dry mass yield, which results in increased $\mathrm{S}$ concentration in leaves. Lower $\mathrm{S}$ accumulation could be observed in the leaves of plants grown in these solutions. In contrast, Salvador et al. (1999) observed that the S contents present in leaves of guava plants grown in solution with the omission of NP were lower than those of leaves grown in complete solution.

A high $\mathrm{K}$ content is observed in zantedeschia leaves when plants are grown in solution with low concentrations of $\mathrm{N}$ and $\mathrm{P}$. A similar effect was observed by Salvador et al. (1999) in guava seedlings. Potassium acts in many physiological processes by activating enzyme systems, favoring a high energy state (required for ATP production), and increases N uptake and protein synthesis (MEURER, 2006). Thus, it could be inferred that when there are lower $\mathrm{N}$ and $\mathrm{P}$ contents in plants, $\mathrm{K}$ tends to concentrate, justifying the high dry mass levels. There is also a greater $\mathrm{K}$ accumulation in leaves when compared to those of plants grown in complete solution.

The highest $\mathrm{K}$ levels were found in leaves when compared to the $\mathrm{K}$ levels present in leaf buds. According to Carneiro et al. (2011), who worked with nutrient accumulation, $\mathrm{K}$ was the most accumulated nutrient among macronutrients, and shoots are the main site of accumulation. 


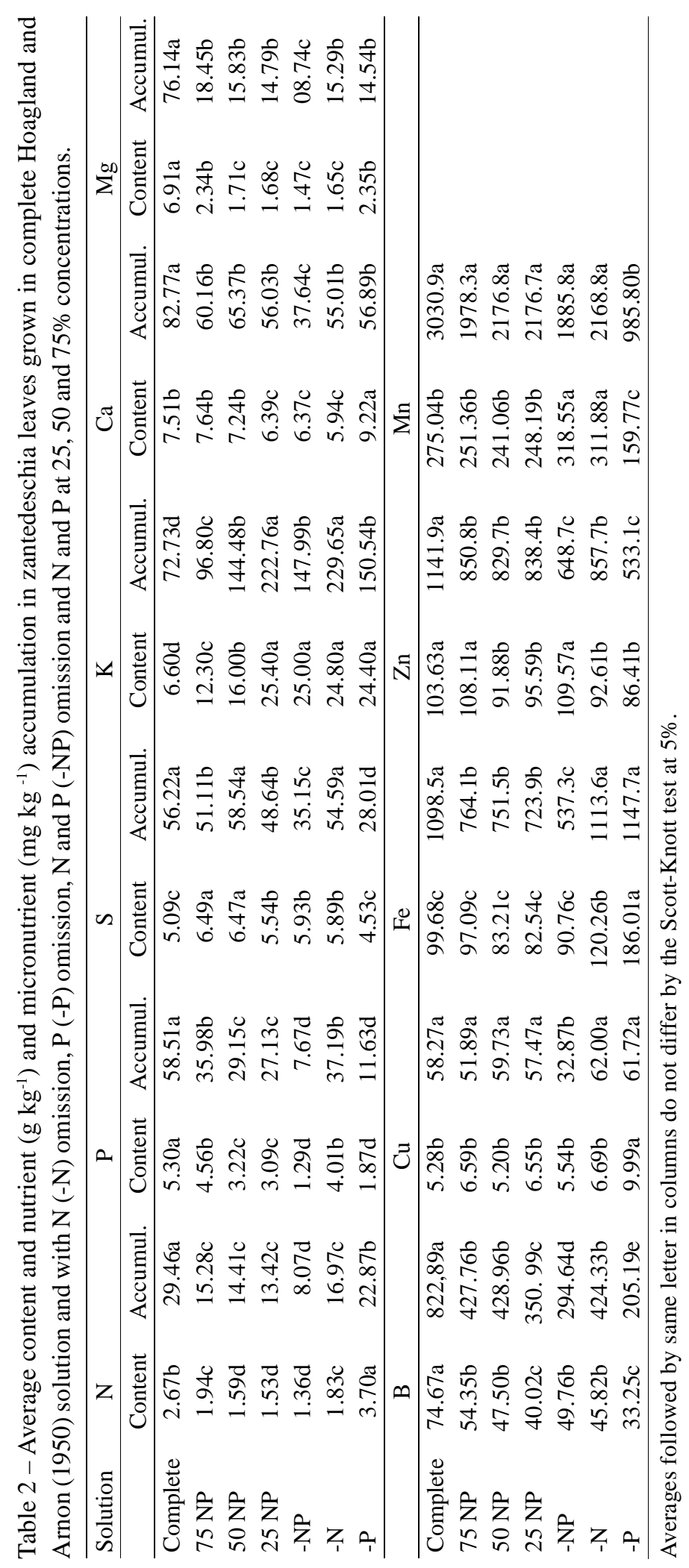

Ciênc. agrotec., Lavras, v. 36, n. 6, p. 631-638, nov./dez., 2012 
In the leaves of plants grown in solution with the omission of $\mathrm{P}$, a high Ca level was observed, when compared to other treatments (Table 2). This may be due to the concentration effect, in which low dry mass yield leads to $\mathrm{Ca}$ accumulation in leaves. However, in leaves of plants grown with multiple omissions of $\mathrm{N}$ and $\mathrm{P}$, the lowest $\mathrm{Ca}$ contents were observed, as in treatments with $25 \mathrm{NP}$ and $\mathrm{NP}$, followed by $-\mathrm{N}$ treatment with low Ca contents (Table 2). Ca content of $6.39 \mathrm{~g} \mathrm{~kg}^{-1}$ is not suitable for a satisfactory development of young zantedeschia plants, and this value was observed in plants grown in solution with $25 \mathrm{NP}$ at 240 days of cultivation, which was lower than $6.75 \mathrm{~g} \mathrm{~kg}^{-1}$, observed by Carneiro et al. (2011) in young zantedeschia plants at 60 days of cultivation.

Lower $\mathrm{Mg}$ accumulation was observed mainly in the leaves of plants grown in - NP solution. The low levels observed of this element and the low dry mass yield resulted in lower $\mathrm{Mg}$ accumulation in leaves. Plants at 240 days of cultivation in solution with multiple omissions of $\mathrm{N}$ and $\mathrm{P}$ showed lower $\mathrm{Mg}$ content than zantedeschia plants at 30 days of cultivation, according to data obtained by Carneiro et al. (2011), of $1.47 \mathrm{~g} \mathrm{~kg}^{-1}$ and $3.38 \mathrm{~g} \mathrm{~kg}^{-1}$, respectively.

The simple or multiple omission of $\mathrm{N}$ and $\mathrm{P}$ affected the B content in leaves (Table 2). Zantedeschia leaves grown in solution with simple omission of $\mathrm{P}$ obtained $\mathrm{B}$ value of $33.25 \mathrm{mg} \mathrm{kg}^{-1}$, which is very close to the lower limit according to Dechen and Nachtigall (2006) for normal growth. B concentrations between 30 and $50 \mathrm{mg} \mathrm{kg}^{-1}$ in the dry mass are considered adequate for normal growth of plants (Dechen and Nachtigall, 2006).

The highest $\mathrm{Cu}$ content $\left(9.99 \mathrm{mg} \mathrm{Kg}^{-1}\right)$ was observed in leaves of plants grown in solution with the omission of $\mathrm{P}$, which according to Carneiro et al. (2011), is suitable for the development of zantedeschia plants.

The simple and multiple omission of $\mathrm{N}$ and $\mathrm{P}$ interfered in the $\mathrm{Zn}$ contents, and plants grown in -P and NP solutions showed lower $\mathrm{Zn}$ accumulation.

In addition, according to Malavolta (2006), excess Fe could induce Mn deficiency. This relationship can be observed by observing the levels of these nutrients in the leaves of plants grown with the omission of P. Leaf buds of plants grown in solution with the omission of $\mathrm{N}$ and $\mathrm{P}$ showed low $\mathrm{N}$ contents, indicating that this nutrient directly affects the formation of new structures in the plant (Table 3).

\section{Content and accumulation of nutrients in zantedeschia leaf buds}

Analyzing the dry mass content in the leaf buds of plants grown in these solutions, low weight was observed, when compared to plants grown in complete solution (Table 3 ). When this is followed by low $\mathrm{N}$ content, it results in lower $\mathrm{N}$ accumulation in leaf buds. This value was expected, since as the $\mathrm{N}$ and $\mathrm{P}$ concentrations in the solution decrease, the $\mathrm{N}$ accumulation in calla lily leaf buds also decreases.

Leaves of plants grown with multiple omission of $\mathrm{N}$ and $\mathrm{P}$ and simple omission of $\mathrm{N}$ showed higher $\mathrm{Mn}$ contents, similar to results obtained by Carneiro et al. (2011) in calla lily plants. According to Malavolta (2006), the presence of $\mathrm{N}_{-} \mathrm{NH}_{4}$ increases the $\mathrm{Mn}$ content in leaves by the effect on availability. Higher Mn contents were found in the leaves of zantedeschia plants compared to leaf buds (Tables 2 and 3).

Leaf buds of plants grown in -NP solution had lower $\mathrm{P}$ content, while plants cultivated in the $75 \mathrm{NP}$ solution may have shown concentration effect, in which the dry mass yield decreased with the partial reduction of $\mathrm{N}$ and $\mathrm{P}$ in the solution, with $\mathrm{P}$ concentration in leaf buds. It could be observed that the macronutrient content in leaf buds grown in $75 \mathrm{NP}$ and complete solution are similar, but the dry mass content is different (Table 3 ).

Leaf buds of plants grown in solution with simple omission of $\mathrm{N}$ and multiple omission of $\mathrm{P}$ and $\mathrm{N}$ had the lowest $\mathrm{S}$ contents. It was observed that in leaf buds grown in solution with $\mathrm{P}$ deficiency and presence of $\mathrm{N}$, the $\mathrm{S}$ content was higher in comparison to leaf buds of plants grown in the other solutions. This may be due to the concentration effect, where the low dry mass yield of plants grown in solution with the omission of $\mathrm{P}$ provided higher $\mathrm{S}$ concentration in leaf buds. $\mathrm{S}$ is not easily remobilized to young leaves in most species (TAIZ; ZEIGER, 2004), which is observed in the low levels found for zantedeschia leaf buds when compared with the leaf levels.

There was no difference in the $\mathrm{K}$ contents in calla lily leaf buds; however, an accumulation of this nutrient was observed in leaf buds of plants grown in solution with $50 \mathrm{NP}$, similarly to leaf buds of plants grown in complete solution. Plants grown in this solution showed the highest number of leaf buds and dry mass yield similar to that of plants grown in complete solution (Table 3). Carneiro et al. (2011) report that K plays an important role in the development of zantedeschia plants, being the most accumulated nutrient. Since leaf bud division is a means of propagating the species for commercial production, $\mathrm{K}$ contents similar to the levels found in leaf buds of zantedeschia plants grown in the complete solution might enhance a higher seedling development in the field. 


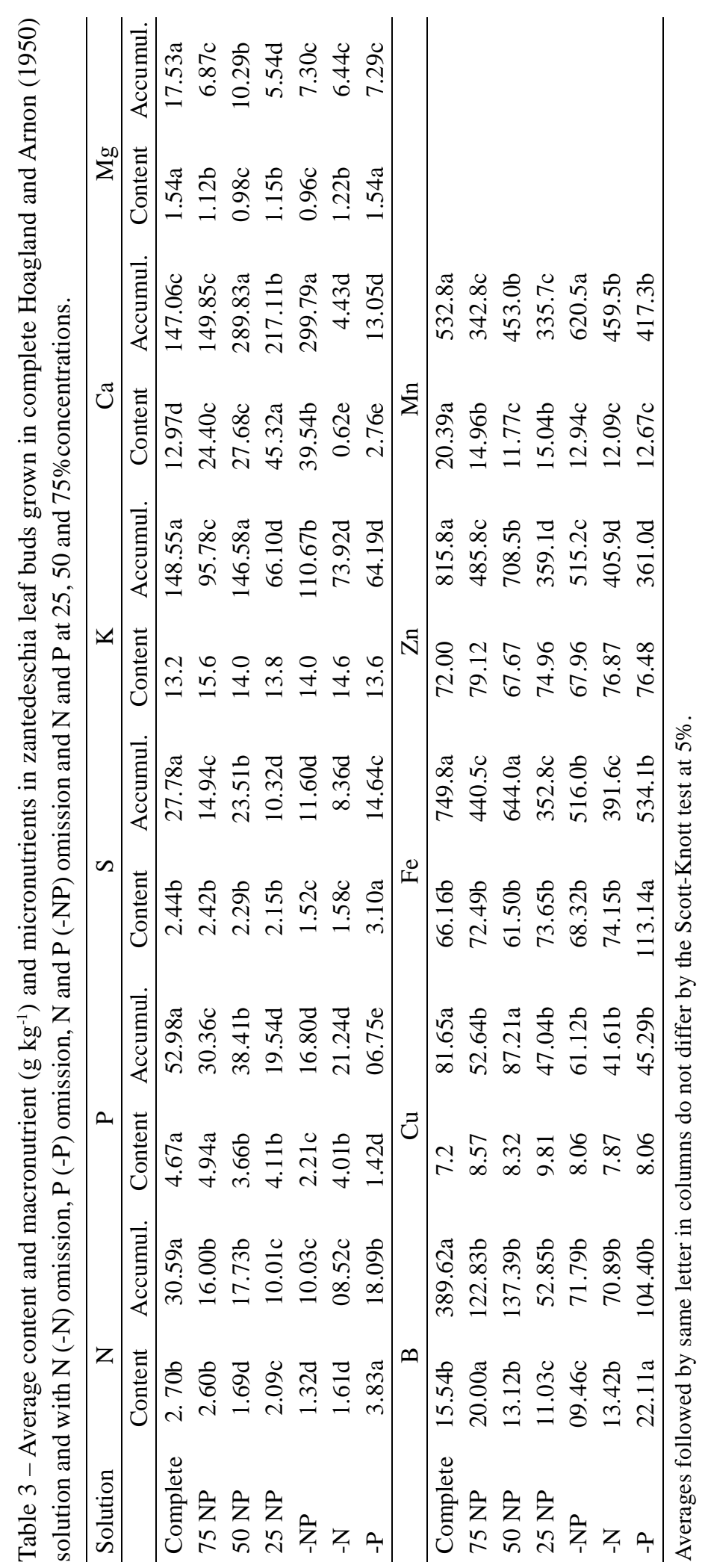

Ciênc. agrotec., Lavras, v. 36, n. 6, p. 631-638, nov./dez., 2012 
Leaf buds of plants grown with multiple omissions of $\mathrm{N}$ and $\mathrm{P}$ showed higher $\mathrm{Ca}$ levels when compared with the $\mathrm{Ca}$ content in leaf buds grown in complete solution. This may be due to the concentration effect of $\mathrm{Ca}$, with the lowest development of leaf buds at lower $\mathrm{N}$ and $\mathrm{P}$ concentrations. In leaf buds of plants grown with simple omission of $\mathrm{N}$ and $\mathrm{P}$, the $\mathrm{Ca}$ content was low compared to those of plants from other treatments. A greater $\mathrm{Ca}$ accumulation was observed in leaf buds when compared to leaves of zantedeschia plants.

Despite the variation in B levels in leaf buds of plants grown in solutions with the omission of $\mathrm{N}$ and $\mathrm{P}$, differences in B accumulation were observed only in leaf buds of plants grown in complete solution. Plants grown in complete solution and with $50 \mathrm{NP}$ showed higher $\mathrm{Cu}$ accumulation. The highest $\mathrm{Cu}$ accumulation in the leaf buds of plants grown in complete solution and with $50 \mathrm{NP}$ may be related to plant propagation, since a higher content of reducing sugars may promote the budding process.

Leaf buds of plants grown in solution with the omission of $\mathrm{P}$ showed Fe levels higher than those of plants grown in complete solution, but with lower Fe accumulation due to lower dry mass development.

There was no difference in the $\mathrm{Zn}$ content in leaf buds of zantedeschia plants grown under simple omission and multiple omissions of $\mathrm{N}$ and $\mathrm{P}$.

In relation to $\mathrm{Mn}$, it could be observed that the multiple omission of $\mathrm{N}$ and $\mathrm{P}$ influenced the contents and accumulation of this nutrient. Leaf buds of plants grown in complete solution showed higher contents and accumulation compared to plants of other treatments.

\section{CONCLUSIONS}

The omission of $\mathrm{N}$ and $\mathrm{P}$, both in simple and multiple forms, affects plant growth leading to fewer leaves, leaf buds, reduced height and decreased dry mass of leaves and leaf buds.

The mineral composition of macronutrients present in leaves and leaf buds of plants is influenced by multiple $\mathrm{N}$ and Pdeficiency. There was decrease in the content and accumulation of nutrients, except $\mathrm{Ca}$ and $\mathrm{K}$ content.

The omission of $\mathrm{N}$ and $\mathrm{P}$ in plants does not influence the $\mathrm{K}, \mathrm{Cu}$ and $\mathrm{Zn}$ contents of zantedeschia leaf buds.

Plants grown in solution and with $50 \mathrm{NP}$ showed similar $\mathrm{Cu}, \mathrm{Fe}$ and $\mathrm{K}$ accumulation in leaf buds.

\section{ACKNOWLEDGEMENT}

The authors would like to thank FAPEMIG and CNPq for their financial support.

\section{REFERENCES}

ALMEIDA, E.F.A. et al. Efeito do silício no desenvolvimento e na nutrição mineral de copo-de-leite. Revista Brasileira de Horticultura Ornamental, Campinas, v.15, n.2, pp. 103-113, 2009.

CARNEIRO, D. N. M. et al. Development and dry mass accumulation in calla lily at the initial cultivation stage.

Ciência e Agrotecnologia, Lavras, v.35, n.6, p. 1085-1092, 2011.

DECHEN, A. R.; NACHTIGALL, G. R. Micronutrientes. In: FERNANDES, M. (Ed.). Nutrição mineral de plantas. Viçosa, MG: Sociedade Brasileira de Ciências do Solo, 2006. cap. 13, p. 327-354.

LANDGRAF, P. R.C.; PAIVA, P. D. O. Agronegócio da floricultura brasileira. Magistra, Cruz das Almas, v.21, n.4, p. 253-261, 2009.

LOBO, D. M. et al. Características de deficiência nutricional do amendoinzeiro submetido à omissão de $\mathrm{N}$, P, K. Bioscience Journal, Uberlândia, v.28, n.1, p.6976,2012 .

EPSTEIN, E.; BLOOM, A. J. Nutrição mineral de plantas: princípios e perspectivas. 2. ed. Tradução Maria Edna Tenório Nunes. Londrina: Planta, 2006. 403 p.

FERREIRA, D. F. Sisvar: a computer statistical analysis system. Ciência e Agrotecnologia, Lavras, v.35, n.6, p.1039-1042, 2011.

FRAZÃO, J. E. M. et al. Deficiência nutricional em bastão-do-imperador (Etlingera elatior (Jack) R. M. Smith): efeito na produção de matéria seca e índices biométricos. Ciência e Agrotecnologia, Lavras, v.34, n.2, p.294-299, 2010.

HOAGLAND, D. R.; ARNON, D. I. The water culture method for growing plants without soils. Berkeley: California Agricultural Experimental Station, 1950. 32 p. (Circular, 347).

LANDGRAF, P. R. C.; PAIVA, P. D. O. Produção de flores cortadas no estado de Minas Gerais. Ciência e Agrotecnologia, Lavras, v.33, n.1, p.120-126, 2009.

MALAVOLTA, E. Manual de nutrição mineral de plantas. São Paulo: Agronômica Ceres, 2006. 638 p. 
MALAVOLTA, E.; VITTI, G. C.; OLIVEIRA, S. A. Avaliação do estado nutricional das plantas: princípios e aplicações. Piracicaba: Potafos, 1997.319 p.

MEURER, E. J. Potássio. In: Nutrição

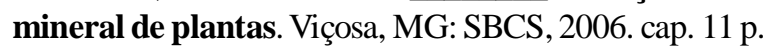
281-298.

SALVADOR, J. O.; MOREIRA, A.; MURAOKA, T. Deficiência nutricional em mudas de goiabeira decorrentes da omissão simultânea de dois macronutrientes. Pesquisa Agropecuária Brasileira, Brasília, v.33, n.10, p.1623-1631,1998.

SALVADOR, J. O.; MOREIRA, A.; MURAOKA, T. Efeito da omissão combinada de N, P, K e S nos teores foliares de macronutrientes em mudas de goiabeira. Scientia Agrícola, Piracicaba, v.56, n.2, p.501-507, 1999.

TAIZ, L.; ZEIGER, E. Fisiologia vegetal. 3. ed. Porto Alegre: Artmed, 2004. 719 p. (Trad.) 